\title{
Fostering Innovation through Knowledge Transfer and Social Capital in The Hospitality Industry
}

\author{
Husaini Hashimi, Nor Lelawati Jamaludin, Siti Salwa Isa, Abu Ali
}

To Link this Article: http://dx.doi.org/10.6007/IJARBSS/v12-i1/12030

DOI:10.6007/IJARBSS/v12-i1/12030

Received: 12 November 2021, Revised: 16 December 2021, Accepted: 27 December 2021

Published Online: 19 January 2022

In-Text Citation: (Hashimi et al., 2022)

To Cite this Article: Hashimi, H., Jamaludin, N. L., Isa, S. S., \& Ali, A. (2022). Fostering Innovation through Knowledge Transfer and Social Capital in The Hospitality Industry. International Journal of Academic Research in Business and Social Sciences, 12(1), 1376-1390.

\section{Copyright: (c) 2022 The Author(s)}

Published by Human Resource Management Academic Research Society (www.hrmars.com)

This article is published under the Creative Commons Attribution (CC BY 4.0) license. Anyone may reproduce, distribute, translate and create derivative works of this article (for both commercial and non0-commercial purposes), subject to full attribution to the original publication and authors. The full terms of this license may be seen at: http://creativecommons.org/licences/by/4.0/legalcode

Vol. 12, No. 1, 2022, Pg. $1376-1390$

Full Terms \& Conditions of access and use can be found at http://hrmars.com/index.php/pages/detail/publication-ethics 


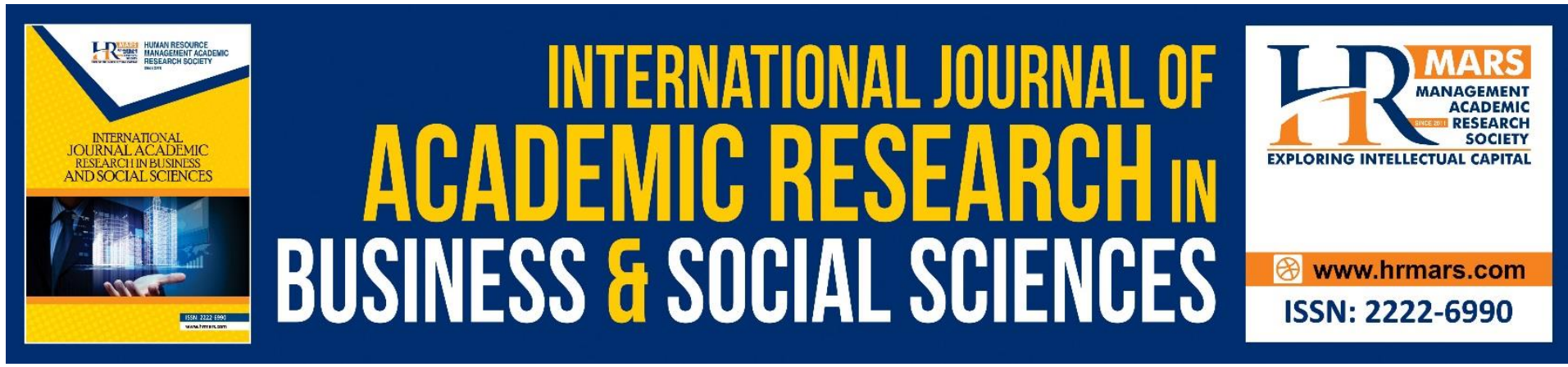

\title{
Fostering Innovation through Knowledge Transfer and Social Capital in The Hospitality Industry
}

\section{Husaini Hashimi ${ }^{1}$, Nor Lelawati Jamaludin², Siti Salwa Isa ${ }^{3}$, Abu $\mathrm{Ali}^{4}$}

${ }^{1}$ Department of Post Graduate Studies, Faculty of Business and Management, Universiti Teknologi MARA, Shah Alam, Selangor, MALAYSIA, ${ }^{2}$ Department of International Business and Management Studies, Faculty of Business and Management, Universiti Teknologi MARA, Puncak Alam, Selangor, Malaysia, MALAYSIA, ${ }^{3 \& 4}$ Department of Industrial Design, Faculty of Art and Design, Universiti Teknologi MARA, Shah Alam, Selangor, MALAYSIA.

Corresponding Author Email: norlelawati0019@uitm.edu.my

\begin{abstract}
Confronted with fierce competition and the current global economic crisis, it becomes a hot topic in the Hospitality Industry on how to maintain and raise revenues. Research has confirmed that shifting focus to innovation presents a new perspective on value creation and increase performance. Thus, this research purposed to measure the innovation creation of employees in hospitality industries through the knowledge transfer process. The respondents are from Hotel Under Marriot International Inc. The data were collected using an online survey among $(n=200)$ top, middle, and lower managers in Malaysia. A structural equation model using SPSS-analysis of moment structures (AMOS) was developed to examine how the variables were related. Results showed that: (1) Knowledge transfer is related to innovation capability; (2) Social capital is related to innovation capability and (3) Social capital is related to knowledge transfer. The novelty of this research is the contribution of the present body of knowledge through the development of the adapted model of knowledge transfer-social capital-innovation capability concerning the hospitality industry. The findings could guide stakeholders and policymakers in formulating plans and action towards the betterment of the knowledge transfer process that can elevate the innovation capability of the organization.

Keywords: Knowledge Transfer, Social Capital, Innovation Capability, Hospitality Industry, Analysis of a Moment Structures (Amos)

\section{Introduction}

The purpose of this study is to look at the link between knowledge transfer, social capital, and innovation in the hotel industry in Malaysia. Until recently, this topic has been disregarded in the context of knowledge transfer-innovation literature in both Malaysian and other corporate contexts, to the best of this researcher's knowledge (Ashtiani, 2014).
\end{abstract}

Innovation is seen as a critical component for organisational success in current competitive corporate world (Tohidi \& Jabbari, 2012; Alrowwad \& Abualoush, 2020). Despite this, 
research on hotel innovation is limited (Escobar 17 \& Parra, 2011; Kessler et al., 2015; Nieves \& Segarra-Ciprés, 2015; Elidemir et al., 2020).

In light of the foregoing, literature has shown that the hotel business must focus on innovation in order to gain a competitive edge in a worldwide and rising market (Kallmuenzer, 2018; Ro-Rama, Ivarez-Garca, \& Coca-Pérez, 2017; Zehrer, Muskat, \& Muskat, 2015). In addition, research by Kandampully et al (2016) and Melhem, Zeffane, and Albaity (2018) found that innovation is one of the most important aspects in gaining a competitive advantage.

According to a study of the databases of major international scientific publications, studies on hotel innovation just began in 2004 (Gomezelj, 2016). Most recent research, on the other hand, have focused on issues such as strategy development, brand management, business intelligence, hospitality management, and customer satisfaction (Fraj, Matute, \& Melero, 2015; Grissemann, Plank, \& Brunner-Sperdin, 2013; Ineson, Rhoden, \& Alexieva, 2011; Kallmuenzer \& Peters, 2018; Nieves \& Segarra Ciprés, 2015; Sutthijakra, 2011; Tang, Only a few others are looking back at earlier studies to see what elements contribute to creativity (Hjalager, 2010; Kallmuenzer, 2018; Kandampully et al., 2016; Law et al., 2014; Li \& Hsu, 2016; Zehrer et al., 2015).

In addition, several studies have looked at the innovation process in hotel chains, claiming that while these businesses have more resources available to engage in innovation, they put in very little effort to focus on the endeavour (Ottenbacher et al., 2005; Tigu, lorgulescu, \& Ravar, 2013). Ottenbacher et al (2005); Köseoglu et al (2020) studies examined hotel chain and independent hotel managers' perceptions of the success elements for innovation. To satisfy the demands of real consumers, the writers discovered weaknesses in the organisational process and knowledge transfer process. As a result, a research in the context of organisational innovation must be designed with an eye on the elements that influence and enhance it in order to generate more effective outcomes in companies and gain a competitive advantage.

Most study on concerns of innovation and hotel services has lately gained prominence in Malaysia (i.e., Ahmad \& Scott, 2019; Balasubramanian \& Ragavan, 2019). Ahmad and Scott (2019) examined at managers from 19 budget and boutique resorts on the Malaysian island of Langkawi. The findings point to a strong link between innovation and increased staff productivity and efficiency. In addition, Asadi et al (2020) emphasise the need of innovation in the hotel business for achieving sustainable growth. According to Law et al (2014), technological progress has altered consumer behaviour. As a result, it is important to control this in order to meet the demands of the customers.

However, before going deeper into the elements that influence organisational innovation, it's critical to understand and analyze where we are currently. Malaysia is placed 33rd out of 131 nations in the Global Innovation Index, according to a study by the Malaysian Investment Development Authority (MIDA) (2020). (GII). Malaysia earned the top spot because to its hightech and creative exports, as well as its prospective scientific and engineering graduates and the quality of its worldwide brands and institutions. However, one of the most significant 
challenges in Malaysia's hotel business is the execution of innovative ideas (Balasubramanian and Ragavan, 2019). As a result, more research into the concerns is required.

Despite this recent success in the Global Innovation Index, 2020, Balasubramanian and Ragavan (2019) said in their study that the Malaysian hospitality sector is now experiencing various concerns and challenges as a result of this change in service innovation. One of the most difficult difficulties in the hotel sector is changing customer expectation (Snehal Mistry, 2021). Guests generally expect a lot more from a hotel. Free WiFi, an entertainment system, unique stay experience, and quick check-in and check-out services are all included. Customers in Malaysia are currently expecting contactless hotel services to ensure a secure stay (Awan, Shamim \& Ahn, 2020). It will definitely be tough to meet these expectations due to a lack of resources or capital bandwidth, but the hospitality sector will be forced to do so by use of appropriate technology and new techniques (Awan, Shamim, \& Ahn, 2020; Snehal Mistry, 2021).

Furthermore, shifts in advertising and marketing trends can be problematic for the hotel business (Sadom, Quoquab, Mohammad, \& Hussin, 2020). Traditional marketing strategies aren't as successful as they once were. As a result, for people who have always followed the traditional practises, this offers one of the industry's most significant obstacles. In their study on the hospitality business in Malaysia, Sadom et al (2020) argued that using creative marketing tactics is a powerful answer to such challenges in the hospitality sector. In addition, the hotel business, especially in Malaysia, has several operational issues (Teck, \& Karuppiah, 2020). Reservations, attending visitors, conducting all front-office activities, keeping cleanliness in hotel rooms and premises, and more are all part of the job (Snehal Mistry, 2021). However, hotel departments frequently fail to complete all jobs in a timely manner, resulting in confusion and client displeasure (Snehal Mistry, 2021). This necessitates the automation of operations and the synchronisation of departmental tasks using an innovative technology, which greatly simplifies communications (Malaysia \& Ismail, n.d.).

In addition, one of the issues facing the hotel industry, particularly Malaysia, is security (Sakolnakorn, 2019). While our data security procedures have progressed significantly, so have the risks of data breaches and malware attacks (Snehal Mistry, 2021). Hoteliers throughout the world are concerned about threats of digital data theft and personal data leaks (Sakolnakorn, 2019; Snehal Mistry, 2021). As a result, the hotel industry must innovate and implement secure hotel technology to prevent data leaks (Kansakar, Munir \& Shabani, 2019).

Some studies (Chen et al., 2017; Chesbrough, 2011; Grissemann et al., 2013) have found that innovation has a favourable impact on corporate success. However, one of the obstacles in Malaysia's hotel business is implementing innovative methods (Balasubramanian and Ragavan, 2019). Inside this line, it is critical to identify main drivers of innovation, and hotel management should be aware of these major drivers in order to execute such innovation plans. Despite prior research (Brunswicker and Chesbrough, 2018; Manville et al., 2019; Saebi and Foss, 2015; Torchia and Calabro, 2019), there is still no consensus on the major drivers of innovation in the hotel business (Saebi and Foss, 2015). In general, the performance of businesses is determined by two factors: knowledge and innovation (Chesbrough, 2012). 
Various studies (Hassi, 2019; Segarra-Ona et al., 2018; Sltten and Mehmetoglu, 2015) have examined the role of knowledge transfer and organisational innovation in the hotel industry; however, these studies have not assessed the role of knowledge transfer and organisational innovation in the hotel industry, which is the motivational factor for this research. Organizational innovation initiatives, according to Pateli and Lioukas (2019), require external knowledge, integration with existing knowledge in multiple functional domains, and transformation into a variety of innovative results. As a result, identifying the linkages between knowledge transfers that drive innovation is critical.

As a result, the study seeks to address a gap in the literature by including knowledge transfer to improve hotel sector innovation. There has been no previous research of this link in the hotel sector, particularly in the Malaysian setting, to the best of the researcher's knowledge.

This is because, knowledge transfer mechanisms have always been at the heart of innovation (Darroch and McNaughton, 2003; Nonaka and Takeuchi, 2007). As stated in the introduction part of this study, the expanding literature on effective knowledge transfer to meet organisational goals such as innovation reflects the growing interest in this topic (Al-Hakim \& Hassan, 2011; Darroch \& McNaughton, 2003; Shahzad et al., 2020). Effective knowledge transfer is frequently cited as a precursor to innovation (Ashtiani, 2014). A review of previous research on the link with both knowledge transfer and innovation reveals some key conclusions, including the fact that knowledge transfer has a large potential to improve organisational innovation (Lin, 2007; Rhodes et al., 2008; Hassan and Al-Hakim, 2011).

Furthermore, innovation contributes significantly to developed-country economic growth (Ghorbani, Mofaredi \& Bashiriyan, 2012), the hospitality industry (Orfila-Sintes \& Mattsson, 2009; Hassi, 2019; Gomilevskaya et al., 2019) and Malaysian hospitality (Al-Shami et al., 2019). Following those significant changes over the last two decades, Malaysian industries found themselves in a new business environment, and they set out to capitalise on the newly discovered business innovation. Innovation and information transfer are currently critical criteria in modern business, attracting Malaysian academics and practitioners (e.g., Bashir \& Farooq, 2019).

In the past, both knowledge-based theory and social capital theory sought to explain knowledge exchange and innovation (Ashtiani, 2014). However, investigations undertaken in each study stream independently of the other have ignored the possible influence of the other hypothesis. In consequence, one may argue that the impact of information transfer on innovation differs in the setting of social capital (Ganguly et al., 2019; Nguyen \& Ha, 2020; Ashtiani, 2014).

Social capital has been shown to influence innovation in studies (Tsai \& Hsu, 2019; Weerakoon et al., 2020). Furthermore, Tsai and Hsu (2019) and Weerakoon, McMurray, Rametse, and Arenius (2020) found that social capital influences knowledge transfer outcomes. As a result, it's critical to dig further into the direct link between social capital, information transmission, and creativity. According to the researcher, this is worth investigating since it would reveal the functions of social capital in the information transfer-innovation link. 
Furthermore, it appears that social capital is the most effective catalyst for creativity (Doloreux \& Parto, 2005). Social capital, on the other hand, encourages collaboration and the interchange of resources and expertise, as well as contributing to creativity (Bengrich, Azzahidi \& Omrane, 2020). Nonetheless, Bengrich and colleagues emphasised that research on the dynamics of social capital, knowledge transfer, and creativity is currently lacking and might be further explored. In response to requests for integrative models that elucidate the implications of knowledge transfer on innovation growth, this study will look into the possible influence of social capital (Ashtiani, 2014; Works, 2019; Fatemi, Sadeghian et al., 2021). Moreover, the Social Capital Theory implies that, notwithstanding the results of a direct association between social capital and knowledge transfer and innovation, social capital has a major effect on the level of knowledge transmission (Chiu et al., 2006; Ganguly, Talukdar \& Chatterjee, 2019; Swanson et al., 2020).

In addition, there is evidence that social capital influences the link between information transmission and innovative capability (see Ashtiani, 2014; Works, 2019; Fatemi et al., 2021). Moreover, in today's competitive corporate world, innovation is seen as a critical component of organisational success (Rasool et al., 2019). This new knowledge should aid in improving forecasts of social capital's impact, laying the framework for future study into the link between knowledge transfer and innovation.

According to the review, well-established models or frameworks for explaining the influence of knowledge transfer and the function of social capital on innovation are still lacking (Yusup, 2020). In conclusion, the statement problem demonstrated the significance of comprehending the link between information transmission and innovation. This study provides a comprehensive look at how these variables interact and impact one another. By linking the social capital viewpoint in the knowledge transfer - innovation domain, it might add to the fields of knowledge transfer research. The findings may also assist stakeholders and policymakers in developing a strategy and taking action to improve the knowledge transfer activity in a company, hence enhancing the organization's innovation.

\section{Literature Review}

\section{Knowledge Transfer and Innovation}

A movement of knowledge among people is known as knowledge transfer. Knowledge transfer can be described as the process whereby people learn by transforming information (Nonaka, Takeuchi, \& Umemoto, 1996). Knowledge transfer, which appears to be one of the main topics of knowledge management at the organisational level, incorporates the exercise and development of value from organisational knowledge (Nambisan, Zahra, \& Luo, 2019).

According to Du Plessis (2007), innovation is the invention of new information and ideas in order to facilitate new business outcomes, such as enhancing internal company processes and structures and developing market-driven products and services. Camisón \& Monfort-Mir, 2012; Victorino et al., 2005; Kandampully et al., 2016; Melhem, Zeffane, \& Albaity, 2018); Camisón \& Monfort-Mir, 2012; Victorino et al., 2005; Kandampully et al., 2016; Melhem, Zeffane, \& Albaity, 2018).

Because innovation is based on knowledge and both are incredibly linked (Iqbal, et al., 2019). The level of knowledge transfer between individuals and organisation has a significant impact 
on knowledge development and innovation (Fujiwara, 2020; Le \& Lei, 2019; Ganguly, Talukdar \& Chatterjee, 2019).

A review of previous research on the relationship between knowledge transfer and innovation reveals some key findings. First, knowledge transfer has shown to have a major impact on organisational innovation (Wang, Li, \& You, 2020; Nonaka \& Takeuchi, 2007; Fujiwara, 2020; Susanty et al., 2016). Furthermore, Zhou et al (2020) argued that internal and external integration of shared knowledge will lead to increased innovation and new product creation, as well as a competitive advantage.

Ibidunni, Kolawole, Olokundun, \& Ogbari (2020); Le \& Lei (2019) stated that knowledge transfer among employees and inside and between teams is a fundamental contributor to knowledge application, innovation, and competitive advantage in a study concentrating on the context for knowledge transfer. Knowledge transfer allows businesses to take advantage of knowledge-based resources and has an impact on a company's ability to innovate (Wang \& Noe, 2010; Kurniawan et al., 2020). Furthermore, when appropriately used, more information transfer enhances the likelihood of higher innovative capability (Nonaka \& Takeuchi, 2007; Zhang et al., 2020). As a result, the researchers believe that more knowledge sharing will lead to increased innovation.

H1: There is a positive and significant relationship between knowledge transfer and innovation.

\section{Social Capital and Innovation}

Widén-Wulff and Ginman (2004) define social capital as "networks, norms, trust, and mutual understanding that bind together the members of human networks and communities and enable participants to act together more effectively to pursue common objectives."

Social capital has a significant influence on innovation (Tsai \& Hsu, 2019; Weerakoon et al., 2020; Zheng et al., 2019). The cognitive and structural components of social capital have favourable benefits on innovative and competitive performance, according to Cappiello et al (2020), but the relational dimension has more diverse effects on innovation and performance. This is due to the fact that producing new knowledge and innovation necessitates individuals exchanging, combining, and sharing diverse resources. When there is a significant cognitive dimension of social capital in situ, these processes can be accelerated (Nahapiet $\&$ Ghoshal, 1998).

Furthermore, according to Zheng et al (2019), social capital is important for corporate innovation and operations. Their research shows that social capital not only allows a company to access a diverse set of information and resources, but it can also help a social network's stakeholders build behavioural standards, communication models, and mutual-trust platforms. As a result, social capital has the potential to help businesses innovate more effectively (Cortes \& Herrmann, 2020). In light of this, the current study aims to investigate the probable link between social capital and innovation.

H2: There is a positive and significant relationship between social capital and innovation. 


\section{Social Capital and Knowledge Transfer}

Social capital influences the outcome of knowledge transfer, according to (Widén-Wulff \& Ginman, 2004; Tsai \& Hsu, 2019; Weerakoon et al., 2020). Liu (2018); Yusup (2018) both published studies on the relationship between social capital and knowledge transfer (2020). Knowledge transfer can also be effected through social capital, according to (Wenger, 2005; Chiu et al., 2006; Swanson et al., 2020).

Furthermore, according to the social capital theory, social capital has a significant impact on the level of interpersonal knowledge transfer (Chiu et al., 2006). In the process of sharing knowledge, social capital acts by providing access to individuals with appropriate knowledge, shared interests, mutual trust, respecting the value of others' knowledge, and having the capability to comprehend, interpret, and recognise the other's knowledge, according to (Van Den Hooff \& Huysman, 2009); Harjanti, \& Noerchoidah, 2017). In light of this, the current study aims to investigate the probable link between social capital and knowledge transfer.

H3: There is a positive and significant relationship between social capital and knowledge transfer.

\section{Method}

\section{Sample and Procedure}

Based on information derived from the Human Resource Department, the population element for this study is employees in the hospitality industry who meet the criteria of organisations with intense knowledge sharing practises that must constantly innovate to ensure the business remains relevant (such as the hospitality industry).

Top, medium, and first-level managers from all Marriot International Inc. hotels in the Klang Valley were tested (Ritz-Carlton, Sheraton, Westin, Aloft, Le Meridien and Four Point by Sheraton). Managers with two or more years of experience who were active in innovation met the inclusion criteria. Managers who did not match the requirements for participation were not allowed to participate.

This study employed stratified random sampling, which is a technique in which a researcher splits a larger population into smaller groups (top, middle, and bottom managers) that don't overlap but yet reflect the full population. The hotel business fit the definition of a knowledge-intensive firm in the context of the research. As a result, this industry has been chosen as the study's population. Hotels under Marriot International Inc. in Klang Valley specialised managerial level as population are service-based hospitality knowledge-intensive sectors.

The proposed data analysis technique for this examination is structural equation modelling (SEM). Taking into consideration suggestions by (Bentler, 1987; Hair, 2010), the minimum total sample size is running from 5 cases for every parameter (40 questions). Thus, the minimum total sample for this research will be 200 respondents. 


\section{Measurement of the Variables Innovation Capability}

Innovation capability was measured by the scale developed by (Jansen et al., (2006). The scale requires ten items to be answered on a 5-point scale (1=strongly disagree to $5=$ strongly agree). An example of the question is: "We introduce improved but existing products and services for our local market".

\section{Knowledge Transfer}

Knowledge transfer was assessed using the scale by Ko, Kirsch, \& King, (2005); Simonin, (1999). An example of the question is: "My interaction with colleagues has increased my understanding of how the knowledge integrates with other knowledge". For each question, respondents answered the question on a 5 -point scale (1=strongly disagree to $5=$ =strongly agree).

\section{Social Capital}

Social Capital was assessed using the scale by Ashtiani, (2014). An example of the question is: "Most members knew each other before they joined this community". For each question, respondents answered the question on a 5 -point scale ( $1=$ strongly disagree to $5=$ strongly agree).

\section{Data Analysis Strategy}

The data for this analysis was evaluated following SEM standards and procedures. To conduct SEM, the two-stage approach suggested by Anderson \& Gerbing (1982) was adopted in this research. The objective of the two-stage approach is to evaluate the measurement model and then to fix the measurement model at the second stage when the structural model is estimated.

\section{Results and Discussion}

\section{Data Screening: Testing of SEM Assumptions}

This section covers the screening and cleansing of data sets before they are further analysed. The data sets were examined for two sorts of issues: 1) case-related issues such data input accuracy, missing values, and outliers, and 2) data distribution issues like normality testing (Tabachnick 2007; Hair 2010). A total of 212 surveys were received, with 10 cases being excluded due to repeated replies to the questions, which they deemed to be suspicious and unreasonable. In addition, two cases were discovered that were unable to reply to all of the questions; as a result, they were deemed to have missed the values to count (Sekaran \& Bougie, 2010). The use of a $5 \%$ cut-off criteria to examine missing values (Tabachnick 2007; Hair 2010) is mentioned below.

Following the missing value evaluation, the data were submitted to an outlier examination. SPSS descriptions were used to compare the z-scores for each example. There were no cases with z-scores greater than 3.29 (p.001). As a result, no univariate outliers have been detected using z-score analysis (Tabachnick, 2007). Multivariate outliers based on Mahalanobis distance (D2) were also assessed. No observations with a D2/df value greater than 3 to 4 are found in the D2 results. The remaining 200 examples were preserved for additional research after the outliers were removed. Following the evaluation of outliers, the data distribution of all observed variables was evaluated. All measurements appear to be within the range of $+/-$ 
1.0 based on the absolute value of skewness and kurtosis. As a result, it's safe to infer that the data set is evenly distributed (Bentler 1987; Schumacker 1996). Finally, the z-statistic of 59.079 in this study is significantly higher than the recommended threshold of $+/-2588$. (Hair, 2010).

\section{Descriptive}

The survey included 200 respondents from all Marriot International Inc. hotels in the Klang Valley, including top, medium, and first-level managers (Ritz-Carlton, Sheraton, Westin, Aloft, Le Meridien and Four Point by Sheraton). This data was collected in January 2020. They ranged in age from 27 to 55 years old, with a median age of 40.66 years. There were 105 men and 95 women among them. The majority of the participants were English native speakers.

\section{The Measurement Model Test}

To optimise all measurements for the structural model, a computation model employing the maximum likelihood estimation approach was used. The first items connected to three primary factors, namely knowledge transfer, social capital, and innovative potential, were subjected to confirmatory factor analysis (CFA). The remaining items had a marginal fit $(\mathrm{cmin} / \mathrm{df})=1.62$, root mean square approximation error $(\mathrm{RMSEA})=0.07$, and comparative fit index $(\mathrm{CFI})=.70$, according to the CFA findings. As a result, this measuring model was employed in all subsequent experiments.

A reliability test was used to assess the internal consistency of numerous measurements for each construct. All Average Variance Extracted (AVE) values are more than 0.5, as indicated in Table 1. Furthermore, the composite dependability was between 0.71 and 0.77 for practically all constructions. Our demonstrates that several tests are valid for evaluating each component in this study (Nunnally, 1978). The factor loadings inside the constructs were used to conduct a construct validity test, and as shown in Table 1, all standardised factor loadings were reasonably high. This demonstrated that the test had convergent validity (Anderson \& Gerbing, 1988).

Table 1

Validity and Reliability Analysis

\begin{tabular}{|l|l|c|c|}
\hline Variables & \multicolumn{1}{|c|}{ Loadings } & AVE & CR \\
\hline Knowledge transfer & 0.85 & 0.51 & 0.71 \\
& 0.65 & & \\
Social capital & 0.50 & & \\
& 0.92 & 0.53 & 0.77 \\
& 0.66 & & \\
Innovation capability & 0.56 & & \\
& 0.76 & 0.57 & 0.73 \\
& 0.69 & & \\
\hline
\end{tabular}

*AVE: Average Variance Extracted, CR: Composite Reliability

The results in Table 2 reveal that discriminant validity has been successfully obtained. Following Hair, Ringle, and Sarstedt (2013), no relationship between the latent variables exceeded 0.9 , showing good discriminant validity. The coefficients of correlation between the 
latent components were not larger than 0.9 in Table 2, indicating that the model is clear of multicollinearity issues (Tabachnick, Fidell, \& Ullman, 2007; Hair et al., 2013). The reliability and validity tests provided sufficient evidence that the constructs fit the requirements for reliability, convergence, and discriminant validity.

Table 2 Discriminant Validity Test

\begin{tabular}{|llll|}
\hline & KT & SC & IC \\
\hline Knowledge transfer (KT) & \multicolumn{1}{c}{0.68} & & \\
Social Capital (SC) & 0.10 & 0.80 & \\
Innovation Capability & 0.42 & 0.08 & 0.73 \\
(IC) & & & \\
\hline
\end{tabular}

\section{The Structural Model Test}

SEM-AMOS was used to check the variables for goodness-of-fit. $\mathrm{cmin} / \mathrm{df}=1.55$, root mean square error of approximation (RMSEA) $=0.07$, and comparative fit index $(\mathrm{CFI})=.90$ are the results for the data regions. The model was judged to have a satisfactory fit to the observed data, according to the results. The correlation between knowledge transfer and innovation capability was found to be positive and significant at the.001 level (=.56). The relationship between social capital and knowledge transfer was found to be positive and statistically significant at the.001 level (=.32). The relationship between social capital and innovative capability was found to be positive and statistically significant at the.001 level (=.38). All characteristics were shown to have positive and substantial (p.001) connections with the theory's direct measurements of innovation capability (knowledge transfer and social capital).

\section{Conclusions}

The impact of information sharing and social capital on innovative potential is significant in this study, as predicted. Knowledge sharing has been shown to have a significant effect on innovation. Individuals inside a company must share any new information they acquire in order to be innovative. Intellectual stimulation can also be achieved through acquiring knowledge from others (knowledge acquisition). In other words, the larger the chance for the formation of fresh ideas and knowledge production, the more knowledge is shared (Kamasak $\&$ Bulutlar, 2010). As a result, innovation emerges from the generation of knowledge (Nonaka \& Takeuchi, 2007; Fujiwara, 2020; Le \& Lei, 2019; Ganguly et al., 2019).

Furthermore, social capital has a significant influence on knowledge transfer (Ali et al., 2021; Ali et al., 2021). This backed up the findings of Weerakoon, McMurray, Rametse, and Arenius (2020), who found that social capital influences knowledge transfer outcomes. Swanson, Kim et al (2020) provided a correlation between social capital and knowledge transfer. Knowledge transfer may be effected through social capital. Furthermore, social capital has a favourable impact on innovation (Tsai \& Hsu, 2019). In this regard, the predicted outcome in this study backed the results by Zheng et al (2019), who claimed that social capital is important to business innovation and is critical in corporate operations, with the ability to increase business innovation (Cortes \& Herrmann, 2020). Finally, in order to evaluate the amount of information transfer and innovation capabilities, this study presents and develops an integrative model that integrates knowledge-based and social capital models. Management's decision to support knowledge sharing might be modified by considering the social capital characteristics of the organization. 


\section{Acknowledgement}

We would like to extend our thanks to the editors and reviewers of the journal, who helped tremendously in improving the quality of this manuscript. Thanks also to the staff at the J.W. Marriot Inc., Malaysia for facilitating the data collection process for this study.

\section{References}

Ahmad, R., \& Scott, N. (2019). Technology innovations towards reducing hospitality human resource costs in Langkawi, Malaysia. Tourism Review.

Ali, M. A., Hussin, N., Haddad, H., Al-Araj, R., \& Abed, I. A. (2021). Intellectual Capital and Innovation Performance: Systematic Literature Review. Risks, 9(9), 170.

Alsaleh, M., \& Abdul-Rahim, A. S. (2021). Determinants of Bioenergy Consumption in the European Continental Countries: Evidence from GMM Estimation. Pertanika Journal of Social Sciences \& Humanities, 29(3).

Anderson, J. C., \& Gerbing, D. W. (1988), 'Structural equation modelling in practice: A review and recommended two-step approach, Psychological Bulletin, vol. 103, no. 3, pp. 411423.

Ashtiani, A. V. (2014). A study on knowledge sharing practices and innovation capability: A social capital perspective (Doctoral dissertation, University Malaya).

awanAsadi, S., Pourhashemi, S. O., Nilashi, M., Abdullah, R., Samad, S., Yadegaridehkordi, E., ... \& Razali, N. S. (2020). Investigating the influence of green innovation on sustainability performance: A case on the Malaysian hotel industry. Journal of cleaner production, $258,120860$.

Balasubramanian, K., \& Ragavan, N. A. (2019). What are the key challenges faced by the Malaysian hospitality and tourism industry in the context of industrial revolution 4.0? Worldwide Hospitality and Tourism Themes.

Bengrich, M., Azzahidi, A., \& Omrane, A. (2020). Contribution of Social Capital to Innovation: The Mediating Role of Knowledge Embedded in Social Networks. Accelerating Knowledge Sharing, Creativity, and Innovation Through Business Tourism, 149-171.

Bentler, P. M., \& Chou, C. P. (1987), 'Practical issues in structural modelling', Sociological Methods \& Research, vol. 16, no. 1, pp. 78-117.

Bryman, A. (2008), Social Research Methods, 3rd edition, Oxford University Press Inc., New York.

Byrne, B. M. (2010), Structural Equation Modeling with AMOS: Basic Concepts, Applications, and Programming, 2nd edn, Taylor \& Francis Group, New York.

Cappiello, G., Giordani, F., \& Visentin, M. (2020). Social capital and its effect on networked firm innovation and competitiveness. Industrial Marketing Management, 89, 422-430.

Chesbrough, H. (2012). Open innovation: Where we've been and where we're going. Research-Technology Management, 55(4), 20-27.

Chesbrough, H., Lettl, C., \& Ritter, T. (2018). Value creation and value capture in open innovation. Journal of Product Innovation Management, 35(6), 930-938.

Chitsaz, E., Tajpour, M., Hosseini, E., Khorram, H., \& Zorrieh, S. (2019). The effect of human and social capital on entrepreneurial activities: A case study of Iran and implications. Entrepreneurship and Sustainability Issues, 6(3), 1393.

Chiu, C. M., Hsu, M. H., \& Wang, E. T. G. (2006). Understanding knowledge sharing in virtual communities: An integration of social capital and social cognitive theories. Decision support systems, 42(3), 1872-88. 
Cortes, A. F., \& Herrmann, P. (2020). CEO transformational leadership and SME innovation: The mediating role of social capital and employee participation. International Journal of Innovation Management, 24(03), 2050024.

Darroch, J., \& McNaughton, R. (2002). Examining the link between knowledge management practices and types of innovation. Journal of Intellectual Capital, 3(3), 210-22.

Fornell, C., \& Larcker, D. F. (1981), 'Evaluating Structural Equation Models with Unobservable Variables and Measurement Error', Journal of Marketing Research, vol. 18, no. 1, pp. 39-50.

Fujiwara, A. (2020). Who is Generating New Innovations? An Analysis of Blockchain Engineers. In 2020 6th International Conference on Information Management (ICIM) (pp. 289-294). IEEE.

Ganguly, A., Talukdar, A., \& Chatterjee, D. (2019). Evaluating the role of social capital, tacit knowledge sharing, knowledge quality and reciprocity in determining the innovation capability of an organization. Journal of Knowledge Management.

Ghorbani, M., Mofaredi, B., \& Bashiriyan, S. (2012). Study of the relationship between intellectual capital management and organizational innovation in the banks. African Journal of Business Management, 6(15), 5208-17.

Gomezelj, D. O. (2016). A systematic review of research on innovation in hospitality and tourism. International Journal of Contemporary Hospitality Management.

Hair, J. F., Black, W. C., Babin, B. J., \& Anderson, R. E. (2010), Multivariate Data Analysis: A Global Perspective, 7th edn, Pearson Prentice Hall, New Jersey.

Harjanti, D., \& Noerchoidah, N. (2017). The effect of social capital and knowledge sharing on innovation capability. Jurnal Manajemen dan Kewirausahaan, 19(2), 72-78.

Ibidunni, A. S., Kolawole, A. I., Olokundun, M. A., \& Ogbari, M. E. (2020). Knowledge transfer and innovation performance of small and medium enterprises (SMEs): An informal economy analysis. Heliyon, 6(8), e04740.

In, J. (2017). Introduction of a pilot study. Korean Journal of anesthesiology, 70(6), 601.

Ineson, E. M., Rhoden, S., \& Alexieva, I. (2011). Success in hotel management: Implications for M-level course design in Bulgaria. Journal of Hospitality, Leisure, Sport \& Tourism Education, 10(02), 30-49.

Iqbal, A., Latif, F., Marimon, F., Sahibzada, U. F., \& Hussain, S. (2019). From knowledge management to organizational performance. Journal of Enterprise Information Management.

Jansen, J. J., Van Den Bosch, F. A., \& Volberda, H. W. (2006). Exploratory innovation, exploitative innovation, and performance: Effects of organizational antecedents and environmental moderators. Management Science, 52(11), 1661-1674.

Kallmuenzer, A. (2018). Exploring drives of innovation in hospitality family firms. International Journal of Contemporary Hospitality Management, 30(3), 1978-1995.

Kamasak, R., \& Bulutlar, F. (2010). The influence of knowledge sharing on innovation. European Business Review, 22(3), 306-17

Kasavan, S., Mohamed, A. F., \& Halim, S. A. (2018). Knowledge and attitudes of hoteliers in Langkawi UNESCO Global Geopark towards sustainable food waste management (SFWM). Pertanika Journal of Social Sciences \& Humanities, 26(3).

Kline, R. B. (2004), Principles and Practice of structural equation modelling, The Guilford Press New York. 
Ko, D.-G., Kirsch, L. J., \& King, W. R. (2005). Antecedents of knowledge transfer from consultants to clients in enterprise system implementation. MIS Quarterly, 29(1), 5985.

Kurniawan, P., Hartati, W., Qodriah, S., \& Badawi, B. (2020). From knowledge sharing to quality performance: The role of absorptive capacity, ambidexterity and innovation capability in the creative industry. Management Science Letters, 10(2), 433-442.

Law, R., Buhalis, D., \& Cobanoglu, C. (2014). Progress on information and communication technologies in hospitality and tourism. International Journal of Contemporary Hospitality Management.

Le, P. B., \& Lei, H. (2019). Determinants of innovation capability: the roles of transformational leadership, knowledge sharing and perceived organizational support. Journal of knowledge management decision.

Liu, C. H. S. (2018). Examining social capital, organizational learning and knowledge transfer in cultural and creative industries of practice. Tourism Management, 64, 258-270.

Malaysia. (2015). Eleventh Malaysia Plan 2016-2020. Kuala Lumpur: Percetakan Nasional Malaysia Berhad.

Malaysia, O. B. I., \& Ismail, A. B. (n.d.). The Relationship Among Business Intelligence Systems Adoption, Information Technology Infrastructure, Innovation And Competitive Environment On Performance. (PhD Thesis)

Nahapiet, J., \& Ghoshal, S. (1998). Social capital, intellectual capital and the organizational advantage. Academy of Management Review, 23(2), 242-266.

Nguyen, H., \& Ha, T. (2020). Social capital and firm performance: A study on manufacturing and services firms in Vietnam. Management Science Letters, 10(11), 2571-2582.

Nonaka, I., \& Takeuchi, H. (2007). The knowledge-creating company. Harvard business review, 85(7/8), 162.

Pateli, A., \& Lioukas, S. (2019). How functional involvement affects the transformation of external knowledge into innovation outcomes. R\&D Management, 49(2), 224-238

Saebi, T., \& Foss, N. J. (2015). Business models for open innovation: Matching heterogeneous open innovation strategies with business model dimensions. European Management Journal, 33(3), 201-213.

Schumacker, R. E., \& Lomax, R. G. (1996), A Beginner's Guide to Structural Equation Modeling, Lawrence Erlbaum Associates, Inc, New Jersey.

Sekaran, U. (2006). Research methods for business: A skill-building approach. John Wiley \& Sons.

Setiawati, C. I., \& Sitorus, P. M. T. (2016). Green Manifestation of Eco-Driver for Excellent Performance. Pertanika Journal of Social Sciences \& Humanities.

Simonin, B. L. (1999). Ambiguity and the process of knowledge transfer in strategic alliances. Strategic Management Journal, 20(7), 595-623.

Sipe, L. J. (2021). Towards An Experience Innovation Canvas: A Framework for Measuring Innovation in the Hospitality and Tourism Industry. International Journal of Hospitality \& Tourism Administration, 22(1), 85-109.

Susanty, A. I., Salwa, M., Chandradini, A., Evanisa, F. W., \& Iriani, N. (2016). Knowledge sharing and implementation of its enabling factors (a case study of three types of company in Indonesia). Pertanika Journal of Social Sciences \& Humanities, 24(1), 239-254.

Swanson, E., Kim, S., Lee, S. M., Yang, J. J., \& Lee, Y. K. (2020). The effect of leader competencies on knowledge sharing and job performance: Social capital theory. Journal of Hospitality and Tourism Management, 42, 88-96. 
Tabachnick, B. G., Fidell, L. S., \& Ullman, J. B. (2007). Using multivariate statistics (Vol. 5, pp. 481-498). Boston, MA: Pearson.

Tsai, F. S., \& Hsu, I. C. (2019). The effects of social capital on knowledge heterogeneity. Management decision.

Wang, L., Li, S., \& You, Z. (2020). The effects of knowledge transfer on innovation capability: A moderated mediation model of absorptive capability and network reliance. The Journal of High Technology Management Research, 31(1), 100372.

Wang, Y., Huang, Q., Davison, R. M., \& Yang, F. (2018). Effect of transactive memory systems on team performance mediated by knowledge transfer. International Journal of Information Management, 41, 65-79.

Weerakoon, C., McMurray, A. J., Rametse, N. M., \& Arenius, P. M. (2020). Social capital and innovativeness of social enterprises: opportunity-motivation-ability and knowledge creation as mediators. Knowledge Management Research \& Practice, 18(2), 147-161.

Wenger, E. (2004). Knowledge management as a doughnut: Shaping your knowledge strategy through communities of practice. Ivey Business Journal, 68(3), 1-8.

Wenger, E. (2005). Communities of practice: A brief introduction. Retrieved October 13, 2005.

Widén-Wulff, G., \& Ginman, M. (2004). Explaining knowledge sharing in organizations through the dimensions of social capital. Journal of Information Science, 30(5), 448-58.

Yuen, Y., \& Ng, X. (2021). Enhancing innovation performance of small and medium enterprises in Malaysia. Management Science Letters, 11(3), 887-894.

Yusup, N. H. (2020). A study on the implication of knowledge transfer and social capital on fostering innovation within the partnership between universities and Technology-Based Small Firms (TBSFs) (Doctoral dissertation, University of Salford).

Zhang, H., Zhang, X., \& Song, M. (2020). Does knowledge management enhance or impede innovation speed? Journal of Knowledge Management.

Zheng, G., Zhu, L., Liu, C., \& Chen, Y. (2019). TMT social capital, network position and innovation: the nature of micro-macro links. Frontiers of Business Research in China, 13(1), 1-23.

Zhou, A. J., Fey, C., \& Yildiz, H. E. (2020). Fostering integration through HRM practices: An empirical examination of absorptive capacity and knowledge transfer in cross-border M\&As. Journal of World Business, 55(2), 100947. 